\title{
Evaluation of in vitro antioxidant and antidiabetic activities from Amomum nilgiricum leaf extract
}

Narasimhamurthy Konappa ${ }^{1_{\ddagger}}$, Udayashankar C Arakere $^{1_{\ddagger}}$, Soumya Krishnamurthy ${ }^{2}$, Kusuma Chathrapalya Gangadharaiah ${ }^{3}$, Vinod Gubbiveeranna ${ }^{3}$, Nagaraju Shivaiah ${ }^{3}$, Srinivas Chowdappa ${ }^{4}$ \& Niranjana Siddapura Ramachandrappa ${ }^{* 1}$

${ }^{1}$ Department of Studies in Biotechnology, University of Mysore, Manasagangotri, Mysore 570 006, Karnataka, India

${ }^{2}$ Field Marshal K.M. Cariappa College, A Constituent College of Mangalore University, Madikeri 571 201, Karnataka, India

${ }^{3}$ Department of Studies and Research in Biochemistry, Tumkur University, Tumkur 572 103, Karnataka, India

${ }^{4}$ Department of Microbiology and Biotechnology, Jnana Bharathi Campus, Bangalore University, Bangalore 560 056, Karnataka, India

${ }^{\ddagger}$ Contributed equally

*Email: niranjanasr@rediff.com

\section{ARTICLE HISTORY}

Received: 02 July 2020

Accepted: 22 September 2020

Published: 23 October 2020

Revised version: 06 January 2020

\section{KEYWORDS}

Amomum nilgiricum

Antioxidant

Antidiabetic

Glucose diffusion

Glucose uptake

Insulin secretion

\section{ABSTRACT}

In the present study, hexane, ethyl acetate and methanol fraction of Amomum nilgiricum leaf was evaluated for antidiabetic efficacy, scavenging activities, followed by estimation of total phenol, total flavonoids. In the present study, a significant amounts of total phenolics $(79.92 \pm 1.58 \mathrm{mg} / \mathrm{g})$ and flavonoids $(21.74 \pm 0.89 \mathrm{mg} / \mathrm{g})$ were showed from Ethyl acetae fraction. $\mathrm{H}_{2} \mathrm{O}_{2}$ scavenging activity $(97.62 \pm 2.89 \%)$ with $\mathrm{IC}_{50}$ value of $78.57 \mu \mathrm{g} / \mathrm{ml}$ concentrations. Ethyl acetate fraction exhibited maximum inhibitory activity of glucose movement into outer solution across dialysis membrane at $250 \mu \mathrm{g} / \mathrm{ml}$ as compared to the control. The ethyl acetate fraction revealed maximum insulin secretory activity $(130.5 \pm 3.66 \%)$ in RIN-m5F cells. Methanol fraction recorded maximum glucose uptake percent in yeast cells $(67.08 \pm 1.68 \%)$ when compared to standard metronidazole $(68.06 \pm 0.73 \%)$. This study scientifically validates the antidiabetic activity of A. nilgiricum. Hence, in view of its comparative hypoglycemic strength, it can work as a valuable healing agent in treating diabetes.

\section{Introduction}

Diabetes is an utmost widespread and prolonged endocrine disease disturbing the metabolism of carbohydrate, lipid and protein (1). The abnormal metabolic disarray characterized by hyperglycemia occurs while either the pancreatic cells do not secrete adequate insulin, or while body cells are unable to successfully use the insulin formed (2). The long-term problems of diabetes contain heart disease, stroke, atherosclerosis leading to dysfunction and organs failure. Based on 2015 World Health Organization (WHO) reports, globally, about 422 million people (aged 20-79) were living with diabetes, and by
2040 it may rise to 650 million $(3,4)$. In India, diabetes population is estimated to be 61.3 million, and it may increase up to 101.2 million until 2030 (5). This large number which accounts for nearly $20 \%$ of the global patients, has deemed India as the world's capital of diabetes $(6,7)$. During the hyperglycemic condition, there is a constant formation of reactive oxygen species (ROS). It is evident that diabetes influences modifications in the actions of the antioxidant enzymes in numerous tissues. This oxidative stress further involved in the improvement and advancement of diabetes related problems. Antioxidants show significant functions in free radicals scavenge with defending cells by

(C) Konappa et al (2020). This is an open-access article distributed under the terms of the Creative Commons Attribution License, which permits unrestricted use, distribution and reproduction in any medium, provided the original author and source are credited (https://creativecommons.org/licenses/by/4.0/).

To cite this article: Konappa N, Arakere U C, Krishnamurthy S, Gangadharaiah K C, Gubbiveeranna V, Shivaiah N, Chowdappa S, Ramachandrappa N S. Evaluation of in vitro antioxidant and antidiabetic activities from Amomum nilgiricum leaf extract. Plant Science Today. 2020;7(4):638-644. https://doi.org/10.14719/pst.2020.7.4.857 
oxidative pressure (8-10). The treatment of diabetes remains a global health challenge. Early-stage diabetes treatment includes the postprandial reduction hyperglycemia by delaying the breakdown of hydrocarbons into absorbable monosaccharides over the prevention of hydrocarbons degrading enzymes viz., aamylase and a-glucosidase present in the gastrointestinal strip. Consequently, declining the pace of glucose absorption also, in turn, dampening the postprandial glucose increase (11).

At present, there are a variety of therapeutic approaches comprising hypoglycemic agents viz., a-glucosidase inhibitors (miglitol, voglibose and acarbose), insulin secretagogues (sulfonylureas and glinides), insulin sensitizers (thiazolidinediones - metformin and pioglitazone). These drugs have limitation in their usage such as generating hypoglycemia at more doses, liver cell injury, lactic acidosis, headache and diarrhoea (12-16). Control of diabetes mellitus (DM) without any side effects is still a challenge to the remedial system. Medicinal plant/plant extracts are effectively used since ancient time for management of diabetes as they are reported to be more effective, less side effects and relatively low cost. According to WHO (2002), medicinal plant/plant extracts are being used to treat diabetes in about $90 \%$ of the population in developing countries. Therefore, identifying and evaluating such plants have become more important (17-20). The WHO has registered 21,000 medicinal plants used around the world and 150 plant species used commercially. Among these 2500 species are reported from the Indian subcontinent. There are about 800 species reported to have antidiabetic activity (21). Most of the plants are known to possess antioxidant with antidiabetic activities. It has been observed that the reduction of lipid peroxidation plus improved antioxidant could decrease diabetes complaints (22).

Amomum nilgiricum V. P. Thomas \& M. Sabu is a recently described species of the family Zingiberaceae (23), from the Western Ghats, Kerala, India. The family comprises with 53 genera with more than 1200 species, numerous of them are generally known for therapeutic uses (24). A. nilgiricum is robust, clump forming habit, stout and non-stoloniferous rhizomes, lanceolate to elliptic-lanceolate, $32-41 \times 6.5-8 \mathrm{~cm}$. Lamina, 2-8 $\mathrm{mm}$ long, petiole, tomentose beneath leaves, $4.5-9 \mathrm{~cm}$ long and persistent ligule, corolla tube is longer than labellum, labellum is not trilobed, uniformly yellow and emarginate anther crest and reduced staminodes (23).

During the current study, the antidiabetic and antioxidant activity of different extracts from $A$. nilgiricum leaves was performed. To assess the efficacy of $A$. nilgiricum extract as antidiabetic agents, we examined the influence on the ability of glucose transport across yeast cell membrane, glucose diffusion and insulin secretion.

\section{Materials and Methods}

\section{Reagents}

Folin Ciocalteu reagent, $\mathrm{NaNO}_{2}$, hydrogen peroxide, gallic acid, $\mathrm{NaCl}, \mathrm{Na}_{2} \mathrm{CO} 3$, glucose, $\mathrm{KCl}$, $\mathrm{NaCl}, \mathrm{MgCl}_{2}, \mathrm{NaH}_{2} \mathrm{PO}_{4}, \mathrm{CaCl}_{2}$.

\section{Plant material collection and extraction}

Amomum nilgiricum was obtained from the region of Western Ghats, Kerala, India at an altitude of $1150 \mathrm{~m}$ mean sea level (MSL). The leaves of the plants were rinsed in water and washed in sterilized distilled water and shade dried. The dehydrated leaf samples were powdered and used for the extraction process. Powdered leaves (100 g) were extracted using a water-ethanol mixture (ratio of 80:10) on a magnetic stirrer for $24 \mathrm{hr}$. The leaf extract was filtered and dried at $40{ }^{\circ} \mathrm{C}$ using vacuum evaporator. The dried crude leaf extract was dissolved in $250 \mathrm{ml}$ of sterilized distilled water for further fractionation. The extracts were separated with methanol, hexane and ethyl acetate and these fractions were dried using vacuum evaporator and used for further studies.

\section{Estimation of total phenols}

The whole content of phenol was estimated by Folin Ciocalteu (FC) as per the standard method (25). In brief, $100 \mu \mathrm{l}$ of fractions was made up to 2 $\mathrm{ml}$ with sterile distilled water and $500 \mu \mathrm{l}$ of FC reagent was added and incubated for $3 \mathrm{~min}$. After incubation, $2 \mathrm{ml}$ of $\mathrm{Na}_{2} \mathrm{CO}_{3}$ was added and the sample was incubated in warm water for $1 \mathrm{~min}$. The content was allowed to cool and the absorbance was recorded at $765 \mathrm{~nm}$ using a spectrophotometer (Elico-Japan). The total phenol content was stated as $\mathrm{mg}$ gallic acid equivalents (GAE) $\mathrm{g}^{-1}$.

\section{Determination of total flavonoids}

The total flavonoids content was assessed as per the standard procedure (26). The reaction mixture comprises $100 \mu \mathrm{l}$ of different fractions and the solution was made up to $2 \mathrm{ml}$ with the distilled water and incubated at room temperature for 3 min. Further, $300 \mu \mathrm{l}$ of $\mathrm{AlCl}_{3}$ and $300 \mu \mathrm{l}$ of $\mathrm{NaNO}_{2}$ was added to the above mixture and the mixture was allowed to stand for $6 \mathrm{~min}$. Then, $1 \mathrm{M}$ of $\mathrm{NaOH}$ solution $(2 \mathrm{ml})$ was added and the final final volume of the reaction mixture was prepared to $10 \mathrm{ml}$ with sterile water. The mixture was allowed to stand for $15 \mathrm{~min}$ and the absorbance was measured at $510 \mathrm{~nm}$. and flavonoid concentration expressed as $\mathrm{mg}$ quercetin equivalent $\mathrm{g}^{-1}$ extract. The total flavonoid content was calculated from a calibration curve and the result was expressed as mg rutin equivalent per g dry weight.

\section{Estimation of antioxidant activity by in vitro methods}

\section{Hydrogen peroxide scavenging capacity}

The hydrogen peroxide $\left(\mathrm{H}_{2} \mathrm{O}_{2}\right)$ scavenging activity of the fractions were performed as per the standard procedure (27). Hydrogen peroxide (40 $\mathrm{mM}$ ) in phosphate buffer was prepared and 
fractions at different concentrations (0.78-100 $\mu \mathrm{g} / \mathrm{ml}$ ) were added with $0.6 \mathrm{ml}$ of distilled water prepared to $3 \mathrm{ml}$ ( $\mathrm{pH}$ 7.4). After $30 \mathrm{~min}$, absorbance was recorded at $230 \mathrm{~nm}$ against a blank solution. Gallic acid was used as as a positive control. The $\% \mathrm{H}_{2} \mathrm{O}_{2}$ scavenging activity was evaluated by the following formula:

\section{$\%$ Radical scavenging activity $=$ Absorbance of the control- absorbance of the sample $\times 100$} Absorbance of the control

\section{Estimation of antidiabetic activity}

\section{Glucose diffusion measurement:}

The Glucose diffusion method was performed according to the standard method (28). The experiment was performed in a dialysis bag $(7.6 \mathrm{~cm} \mathrm{x}$ $15 \mathrm{~mm}$, dialysis tubing cellulose membrane, Sigma Aldrich), $6 \mathrm{ml}$ of fractions was added into dialysis bag, along with $2 \mathrm{ml} 0.15 \mathrm{M}$ Sodium chloride containing $0.22 \mathrm{mM}$ glucose. The closed dialysis tubing positioned in a centrifuge tube comprising 100 $\mathrm{ml}$ of $0.15 \mathrm{M} \mathrm{NaCl}$ in an orbital shaker and incubated for $3 \mathrm{hr}$ at $37^{\circ} \mathrm{C}$. Amount of glucose inside the dialysis tube was recorded and control contains $2 \mathrm{ml}$ of 0.15 $\mathrm{M} \mathrm{NaCl}$ having $0.22 \mathrm{mM}$ glucose with $1 \mathrm{ml}$ distilled water. The glucose movement into the outer solution was examined each half an hour using glucose oxidase peroxidase diagnostic kit (Sigma-Aldrich). The glucose concentration was verified every $30 \mathrm{~min}$ for $3 \mathrm{hr}$. The glucose diffusion retardation index (GDRI) was calculated using the following formula: GDRI $=(100-$ glucose content $(\mu \mathrm{g} / \mathrm{ml})$ in external solution in the presence of sample /glucose content $(\mu \mathrm{g} / \mathrm{ml})$ in external solution in the absence of sample) $\times 100$.

\section{Glucose uptake in yeast cells}

Glucose uptake in yeast cell was evaluated as per the standard procedure (29). The baker's yeast (Saccharomyces cerevisiae) was subjected to repetitive centrifugation (Thermo Fischer) $(3000$ rpm, for $5 \mathrm{~min}$ ) in distilled water until the supernatant fluids were was clear and a $10 \%$ (v/v) uspension was prepared in distilled water. Leaf extract fractions of $50-250 \mu \mathrm{g} / \mathrm{ml}+1 \mathrm{ml}$ of 5,15 and $25 \mathrm{mM}$ glucose solution added and incubated at $37^{\circ} \mathrm{C}$ for $10 \mathrm{~min}$. The reaction was initiated by addition of $100 \mu \mathrm{l}$ yeast suspension to the combination of glucose and fractions was mixed and incubated at $37^{\circ} \mathrm{C}$ for $1 \mathrm{hr}$. It is centrifuged at (2500 rpm for $5 \mathrm{~min}$ ), and the quantity of glucose in the sample is assessed by using a spectrophotometer at $520 \mathrm{~nm}$. The $\%$ of glucose uptake was determined by:

Glucose uptake $(\%)=$ Abs control - Abs fractions $/$ Abs control $\times 100$

\section{Insulin secretion assay}

The amount of insulin released by RIN-m5F cells was estimated (30). Cells RIN-5F cell line was obtained from National Centre for Cell Science, Pune, India. The RIN-m5F cells $\left(10^{5}\right.$ cells $\left./ \mathrm{ml}\right)$ was isolated in fresh RPMI-1640 growth medium (supplementary with 1 mM sodium pyruvate, $10 \%$ FBS, $10 \mathrm{mM}$ HEPES) $90 \%$; fetal bovine serum $10 \%$, antibiotics $(100 \mu \mathrm{g} / \mathrm{ml}$ streptomycin, $100 \mathrm{IU} / \mathrm{ml}$ penicillin $\mathrm{G}$, and $2.5 \mu \mathrm{g} / \mathrm{ml}$ amphotericin B) added $0.2 \mathrm{ml}$ into 96-well plates. Plate kept in a $5 \% \mathrm{CO}_{2}$ incubator at $37^{\circ} \mathrm{C}$ for $48 \mathrm{hr}$, after incubation, the medium was removed and cells incubated in glucose-free Krebs-Ringer (KRB) buffer (3.6 mM KCl, $1.5 \mathrm{mM} \mathrm{CaCl}_{2}, 135 \mathrm{mM} \mathrm{NaCl}, 5 \mathrm{mM}$ $\mathrm{NaHCO}_{3}, 0.5 \mathrm{mM} \mathrm{MgCl}_{2} 0.5 \mathrm{mM} \mathrm{NaH}_{2} \mathrm{PO}_{4}$ ) added with $1 \mathrm{mg} / \mathrm{ml} \mathrm{BSA}$ and $10 \mathrm{mM}$ HEPES incubated for $2 \mathrm{hr}$. The growth medium removed and substituted by $100 \mu \mathrm{l}$ of glucose-free KRB comprising different concentrations $\quad(50-250 \quad \mu \mathrm{g} / \mathrm{ml}) \quad$ fractions. Glibenclamide $(1,10,100 \mu \mathrm{M})$ acts as a positive control. After one hr of incubation, aliquots of $25 \mu \mathrm{l}$ of media was collected from every well and assessed for the amount of insulin. The insulin content was estimated by DRG diagnostic insulin ELISA kit by: \% of insulin secreted $=[$ (Abs treated cells/Abs control cells) $\times 100]-100$. The quantity of insulin secreted was expressed as $\mu \mathrm{U} / \mathrm{ml}$.

\section{Result}

\section{Total phenolic and flavonoid contents}

The total phenolic and flavonoid contents from ethyl acetate, hexane, methanol, and aqueous fractions of $A$. nilgiricum leaves were shown in Fig. 1. The ethyl acetate fraction showed maximum phenolic content $(79.92 \pm 1.58 \mathrm{mg} / \mathrm{g})$ while methanol, hexane and aqueous fractions showed $47.67 \pm 0.66$ $\mathrm{mg} / \mathrm{g}, \quad 37.46 \pm 1.12 \mathrm{mg} / \mathrm{g}$ and $65.51 \pm 1.83 \mathrm{mg} / \mathrm{g}$ respectively. The ethyl acetate fraction showed maximum flavonoid content $(21.74 \pm 0.89 \mathrm{mg} / \mathrm{g})$ while methanol, hexane and aqueous fractions showed $19.76 \mathrm{mg} / \mathrm{g}, 18.64 \mathrm{mg} / \mathrm{g}$ and $9.51 \mathrm{mg} / \mathrm{g}$ respectively.

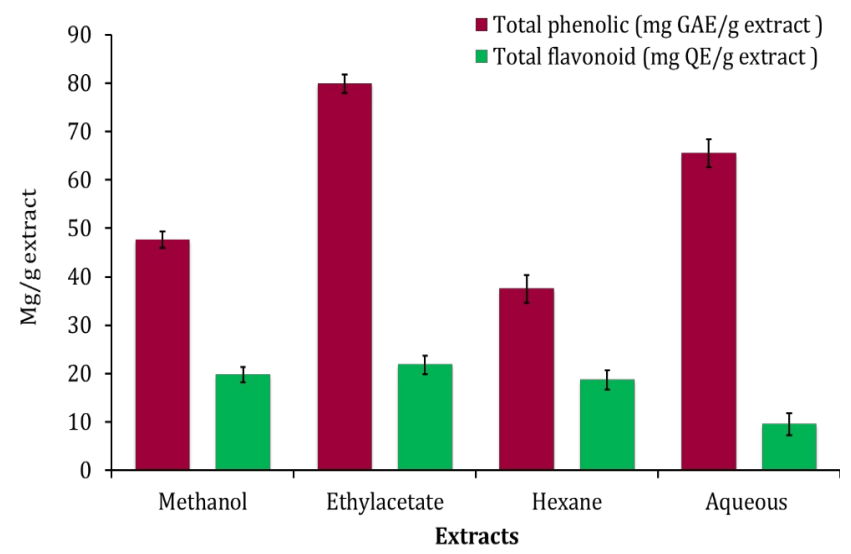

Fig. 1. Determination of total phenolic and flavonoid from different fractions of $A$. nilgiricum leaves.

\section{$\mathrm{H}_{2} \mathrm{O}_{2}$ scavenging activity}

The scavenging capacity of fractions on hydrogen peroxide was shown in Fig. 2. The A. nilgiricum leaves fractions were capable of scavenging $\mathrm{H}_{2} \mathrm{O}_{2}$ in a dose dependent manner. The ethyl acetate fraction showed maximum $\mathrm{H}_{2} \mathrm{O}_{2}$ scavenging activity of $97.62 \pm 2.89 \%$ followed by methanol $(90 \pm 1.33 \%)$, hexane $(86.43 \pm 1.56 \%)$ and water fraction was revealed lowest $\mathrm{H}_{2} \mathrm{O}_{2}$ scavenging activity of $85 \pm 1.89 \%$. The $\mathrm{IC}_{50}$ values as follows: ethyl acetate $-78.57 \mu \mathrm{g} / \mathrm{ml}$, methanol $-83.62 \mu \mathrm{g} / \mathrm{ml}$, hexane $-92.38 \mu \mathrm{g} / \mathrm{ml}$ and 
aqueous fraction - $115.57 \mu \mathrm{g} / \mathrm{ml}$. The standard, gallic acid, showed $62.33 \mu \mathrm{g} / \mathrm{ml}$.

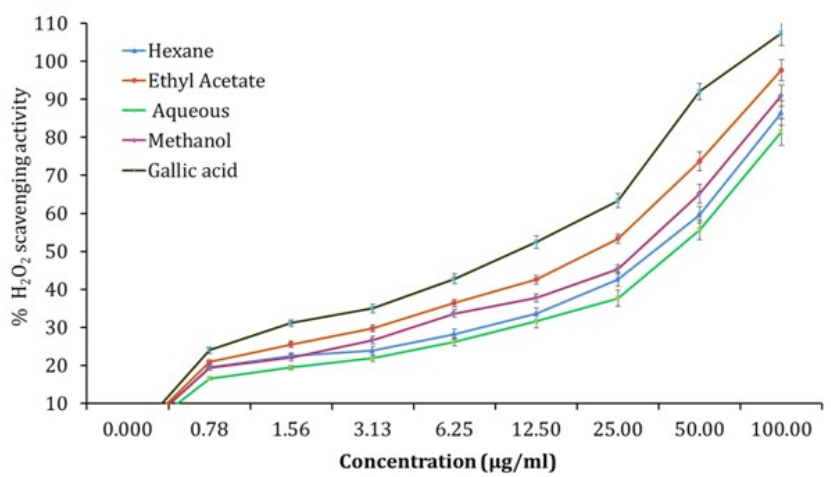

Fig. 2. $\mathrm{H}_{2} \mathrm{O}_{2}$ scavenging activity of different fractions of $A$. nilgiricum leaves.

\section{In vitro glucose diffusion}

The effects of different fractions tested upon glucose diffusion in-vitro are shown in Fig. 3a. Glucose diffusion assay was conducted to examine the influence of different fractions of leaf extracts with respect to its glucose retardation activity across the dialysis tube. The glucose diffusion at the different times assayed was significantly different between the fractions. The amount of glucose diffusion was recorded to increase from 30 to $180 \mathrm{~min}$. Ethyl acetate fraction showed inhibitory effects on transmission of glucose into the outside solution across the dialysis membrane and aqueous fraction was showed minimum inhibition to the diffusion of glucose as related to the control. For all fractions, the rate of glucose transfer into external solution was lesser than control. The fractions were exhibited GDRI between $19 \%$ and 26\%. GDRI (\%) reduced with decreasing concentration of the fractions (Fig. 3b). The aqueous fraction was revealed to show better GDRI at $250 \mu \mathrm{g} / \mathrm{ml}$ concentration.

\section{Glucose uptake in yeast cells}

The effect of fractions on glucose uptake across yeast cell membrane was determined in-vitro system containing yeast cells suspended in a 5, 15, $25 \mathrm{mM}$ glucose solution at different concentrations (Fig. 4).The result of metronidazole on glucose uptake by the yeast cells at $25 \mathrm{mM}$ glucose was a little higher as compared to the fractions. All the fractions increased yeast cells glucose uptake. Among the fractions, methanolic fraction was showed maximum glucose uptake of $67.08 \pm 1.68 \%$ which was nearly close to the standard metronidazole, i.e. $68.06 \pm 0.49 \%$, $71.06 \pm 2.62 \%, 71.06 \pm 2.62 \%$ concentrations at $5 \mathrm{mM}, 15$ mM, 25 mM respectively (Table 1).

\section{Insulin secretion assay}

The effect of fractions on insulin secretion was evaluated on RIN-m5F cell lines. The fractions significantly stimulated the insulin secretion in RINm5F pancreatic cells in comparison to Glibenclamide (Fig. 5). The ethyl acetate fraction was revealed maximum insulin secretory effect on RIN-m5F cells when when compared to other fractions. A dosedependent increase in insulin secretion was significantly improved from different concentrations
Table 1. Percentage of glucose uptake in yeast cells treated with $A$. nilgiricum leaf extracts fractions with 5,15 and $25 \mathrm{mM}$ glucose concentration.

\begin{tabular}{|c|c|c|c|c|}
\hline Extracts & $\begin{array}{c}\text { Concentrati } \\
\text { on }(\mu \mathrm{g} / \mathrm{ml})\end{array}$ & $\begin{array}{l}\text { Inhibition } \\
\text { (\%) at } 5 \mathrm{mM} \\
\text { glucose }\end{array}$ & $\begin{array}{c}\text { Inhibition } \\
\text { (\%) at } 15 \\
\text { mM } \\
\text { glucose } \\
\end{array}$ & $\begin{array}{l}\text { Inhibition } \\
\text { (\%) at } 25 \\
\text { mM glucose }\end{array}$ \\
\hline \multirow{5}{*}{$\begin{array}{l}\text { Metronidaz } \\
\text { ole }\end{array}$} & 50 & $44.87 \pm 0.98$ & $38.92 \pm 0.66$ & $25.78 \pm 0.57$ \\
\hline & 100 & $49.78 \pm 1.28$ & $44.97 \pm 0.57$ & $28.46 \pm 0.68$ \\
\hline & 150 & $54.95 \pm 1.16$ & $50.65 \pm 089$ & $32.66 \pm 0.89$ \\
\hline & 200 & $65.98 \pm 1.33$ & 62.891 .34 & $35.12 \pm 0.76$ \\
\hline & 250 & $77.66 \pm 1.125$ & $71.54 \pm 1.66$ & $36.34 \pm 0.98$ \\
\hline \multirow{5}{*}{$\begin{array}{l}\text { Ethyl } \\
\text { acetate }\end{array}$} & 50 & $35.74 \pm 0.98$ & $31.32 \pm 0.57$ & $18.67 \pm 0.57$ \\
\hline & 100 & $37.89 \pm 1.37$ & $32.87 \pm 0.66$ & $21.43 \pm 0.56$ \\
\hline & 150 & $38.65 \pm 1.56$ & $39.66 \pm 0.78$ & $25.54 \pm 0.43$ \\
\hline & 200 & $51.42 \pm 1.89$ & $48.32 \pm 1.12$ & $29.76 \pm 0.89$ \\
\hline & 250 & $69.06 \pm 2.13$ & $61.54 \pm 1.56$ & $34.67 \pm 0.66$ \\
\hline \multirow{5}{*}{ Methanol } & 50 & $36.76 \pm 1.46$ & $33.23 \pm 0.66$ & $21.66 \pm 0.6$ \\
\hline & 100 & $39.99 \pm 1.63$ & $35.76 \pm 0.57$ & $25.87 \pm 0.89$ \\
\hline & 150 & $47.75 \pm 1.83$ & $42.18 \pm 1.32$ & $28.45 \pm 0.57$ \\
\hline & 200 & $59.42 \pm 2.26$ & $52.65 \pm 1.45$ & $33.23 \pm 0.98$ \\
\hline & 250 & $71.06 \pm 2.62$ & $65.87 \pm 2.12$ & $36.56 \pm 0.57$ \\
\hline \multirow{5}{*}{ Hexane } & 50 & $28.64 \pm 0.66$ & $21.78 \pm 0.89$ & $19.34 \pm 0.66$ \\
\hline & 100 & $32.97 \pm 1.32$ & $28.54 \pm 0.66$ & $21.34 \pm 0.56$ \\
\hline & 150 & $36.85 \pm 1.11$ & $32.76 \pm 0.89$ & $24.91 \pm 0.89$ \\
\hline & 200 & $45.44 \pm 1.34$ & $38.33 \pm 0.87$ & $29.45 \pm 0.54$ \\
\hline & 250 & $61.43 \pm 1.89$ & $59.43 \pm 1.46$ & $31.66 \pm 0.48$ \\
\hline \multirow{5}{*}{ Aqueous } & 50 & $29.51 \pm 0.98$ & $21.43 \pm 0.78$ & $17.67 \pm 0.33$ \\
\hline & 100 & $35.23 \pm 1.21$ & $27.45 \pm 0.66$ & $19.32 \pm 0.78$ \\
\hline & 150 & $37.62 \pm 1.16$ & $31.89 \pm 0.57$ & $21.43 \pm 0.66$ \\
\hline & 200 & $49.77 \pm 1.57$ & $40.65 \pm 1.33$ & $26.87 \pm 0.98$ \\
\hline & 250 & $63.55 \pm 1.98$ & $48.76 \pm 1.63$ & $29.78 \pm 0.73$ \\
\hline
\end{tabular}

Results are expressed as mean \pm SE $(n=3)$ of three independent experiments.

of $62.5 \mu \mathrm{g} / \mathrm{ml}$ to $500 \mu \mathrm{g} / \mathrm{ml}$ as compared to Glibenclamide $(1,10,100 \mu \mathrm{M})$.

\section{Discussion}

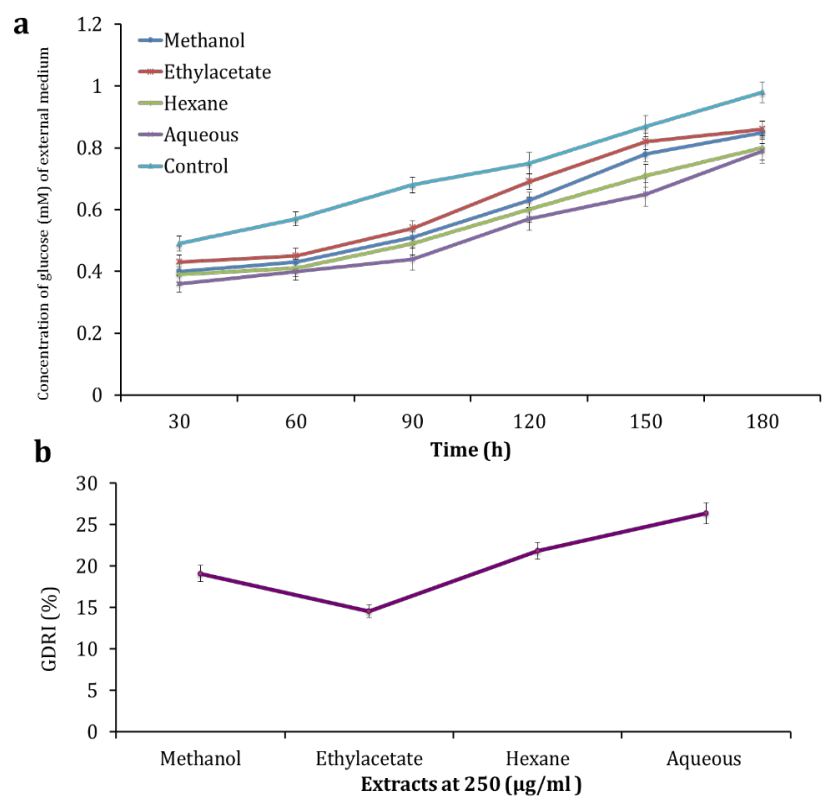

Fig. 3. Effect of different fractions of A. nilgiricum leaves on the diffusion of glucose across the dialysis membrane. a) Diffusion of glucose across the dialysis tube at $250 \mu \mathrm{g} / \mathrm{ml}$ at different time intervals. b) Glucose diffusion retardation index after $3 \mathrm{hr}$ at 250 $\mu \mathrm{g} / \mathrm{ml}$ concentration. 


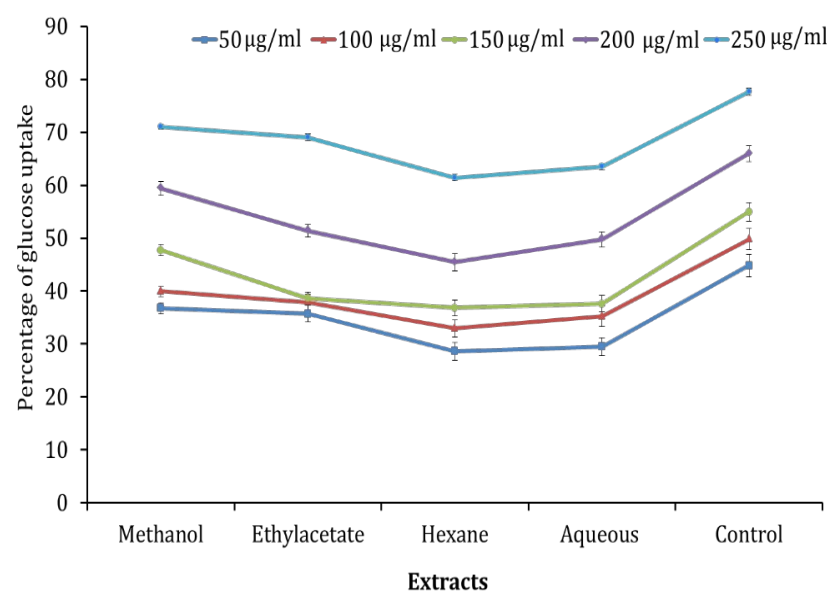

Fig. 4. Percentage of glucose uptake in yeast cells treated with different fractions of $A$. nilgiricum leaves.

Diabetes mellitus is one of the growing metabolic disorder worldwide. The defectiveness in the energy regulation and metabolism of the body because of insulin resistance otherwise scarcity to elevated blood sugar points leading to numerous problems in diabetes (31). Medicinal plants have been used in traditional/ayurvedic usage to treat Diabetes mellitus, especially in developing countries (32). The phytocomponents of the plant extracts which show hypoglycemic effect may work separately or synergistically $(33,34)$. Further, the secondary plant metabolites associated with antioxidants prevent the damage of pancreatic beta cell due to oxidative stress.

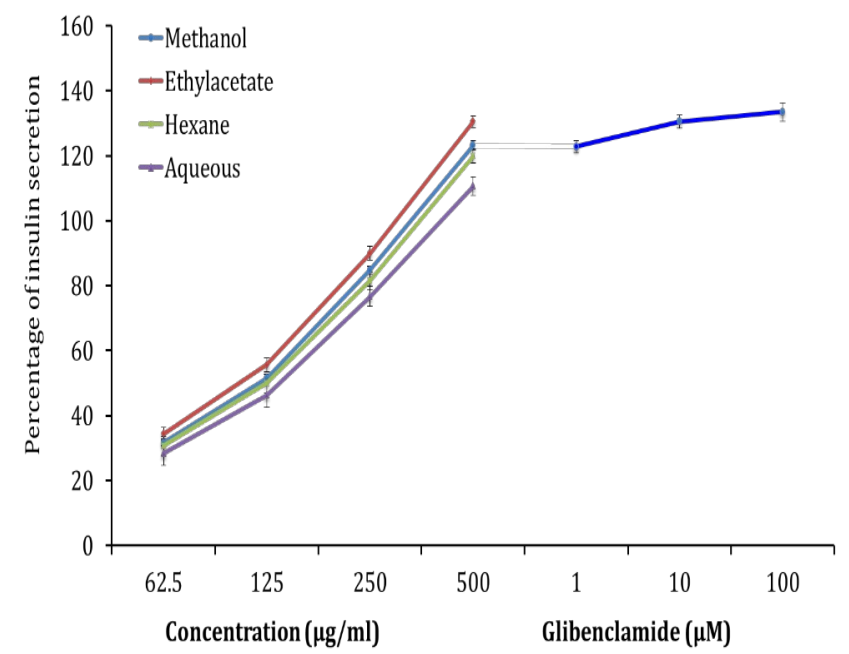

Fig. 5. Effect of different fractions of $A$. nilgiricum leaves on insulin secretion in RIN-m5F pancreatic cells. Glibenclamide was used as a positive control in glucose free medium.

The a-amylase and a-glucosidase enzymes hydrolyze $a-1,4$-glucosidic linkages to liberate $a$ glucose. Inhibition of these enzymes expressively reduces the postprandial acceleration in blood glucose (11). Earlier studies suggested that plantderived phenolics have significantly inhibited $\alpha$ amylase and $\alpha$-glucosidase activities (35-37). The side effect of diabetes drugs is mainly due to extreme inhibition of pancreatic $\alpha$-amylase resultant in the irregular bacterial fermentation of unused sugars in the colon (38).
The plant fractions dose-dependently increased the glucose uptake in yeast cells. The transport of glucose across the yeast cell membrane is an effective model to evaluate the hypoglycemic effect (39). Glucose uptake is mediated by stereospecific membrane carriers (40). The methanol fraction of $A$. nilgiricum leaves exhibited the maximum glucose transport across yeast cells followed by ethyl acetate, hexane and aqueous fractions.

A. nilgiricum leaves fractions inhibited the amount of glucose diffusion across the membrane; hence, they can act as a promising inhibitor in dropping the blood glucose level by inhibiting the movement of glucose molecule across the plasma membrane into the blood vessel. Ethyl acetate fraction exhibited potent inhibitory effects compared to control. This indicates that $A$. nilgiricum leaves extract can significantly inhibit glucose diffusion (41). The glucose GDRI is beneficial in-vitro index to calculate the efficiency of fractions on the delay in glucose absorption in the intestinal tract $(42,43)$. The aqueous fraction was recorded to have the maximum GDRI value at $250 \mu \mathrm{g} / \mathrm{ml}$ concentration. Similar studies have been reported in soluble fibres, for example, oats, wheat bran and psyllium husk were showed to prevent between 10 and 23\% glucose transmission (44).

Insulin secretory activity could be due to natural substances present in the plant extract, which stimulates insulin secretion or protects the intact functional $\beta$-cells from further deterioration, so that they remain active and continue producing insulin. Terpenoids and polyphenols from medicinal plants are known to stimulate the pancreatic beta-cell resulting in secretion of insulin $(45,46)$.

\section{Conclusion}

The result of the current research indicates $A$. nilgiricum leaf extracts exhibited antioxidant property, exhibited in-vitro glucose diffusion, glucose uptake by yeast cells and stimulated insulin-secreting effect on RIN m5F pancreatic cell lines. Further, isolation and evaluation of bioactive molecules could be helpful for the discovery of new medicines to control diabetes mellitus.

\section{Acknowledgements}

This work was supported by University Grant Commission (UGC), New Delhi, Post-Doctoral Fellowship (No. F./PDFSS-2014-15-ST-KAR-7487). The authors also thankful to Department of Forests and Wildlife, Govt. of Kerala for providing necessary forest permission for sample collection.

\section{Authors' contributions}

NK, UAC, SK did the experiments, NK, UAC, KCG, VG, NS, SC, NSR wrote the manuscript, NK, UAC, KCG, VG, NS, SC, NSR and SK read the manuscript and made suitable changes. 


\section{Conflict of interests}

The authors declare that they have no conflict of interest.

\section{References}

1. Alqahtani N, Khan WA, Alhumaidi MH, Ahmed YA. Use of glycated haemoglobin in the diagnosis of diabetes mellitus and pre-diabetes and role of fasting plasma glucose, oral glucose tolerance test. Int J Prev Med. 2013;4(9):1025-29.

2. Cherbal A, Kebieche M, Yilmaz EM, Aydogmuş Z, Benzaouia L, Benguessoum M, Madani K. Antidiabetic and hypolipidemic activities of Algerian Pistacia lentiscus L. leaves extract in alloxan-induced diabetic rats. S Afr J Bot. 2017;108:157-62. https://doi.org/10.1016/j.sajb.2016.10.024

3. Rahimi M. A review: antidiabetic medicinal plants used for diabetes mellitus. Bull Env Pharmacol Life Sciences. 2015;4(2):163-80.

4. Kooti W, Farokhipour M, Asadzadeh Z, Ashtary-Larky D, AsadiSamani M. The role of medicinal plants in the treatment of diabetes: a systematic review. Electron Physician. 2016; 8(1):1832-42. https://doi.org/10.19082/1832

5. Robert A, Al Dawish MA, Braham R, Musallam MA, Al Hayek AA, Al Kahtany NH. Type 2 diabetes mellitus in Saudi Arabia: major challenges and possible solutions. Curr Diabetes Rev. 2016;13(1):59-64.

6. Datta A, Bagchi C, Das S, Mitra A, Pati AD, Tripathi SK. Antidiabetic and anti- hyperlipidemic activity of hydroalcoholic extract of Withania coagulans Dunal dried fruit in experimental rat models. J Ayurveda Integr Med. 2013;4(2):99-106. https://doi.org/0.4103/0975-9476.113880

7. Roy A, Mahalingam G. The in-vitro antidiabetic activity of Phoenix roebelenii leaf extract. Int J Green Pharm. 2017;11(1):128-34. https://doi.org/ 10.22377/ijgp.v11i01.884

8. Day C. Traditional plant treatments for diabetes mellitus: pharmaceutical foods. $\mathrm{Br} \quad \mathrm{J}$ Nutr. 1998;80:203-08. https://doi.org/10.1017/S0007114598001718

9. Eurich DT, McAlister FA, Blackburn DF, Majumdar SR, Tsuyuki RT, Varney J et al. Benefits and harms of antidiabetic agents in patients with diabetes and heart failure: systematic review. Br $\begin{array}{lll}\text { Med J. 2007;335(7618):497-501. } & \end{array}$ https://doi.org/10.1136/bmj.39314.620174.80

10. Ahmed RG. The physiological and biochemical effects of diabetes on the balance between oxidative stress and antioxidant defense system. Med J Islamic World Acad Sci 2005;15(1):31-42.

11. Wojdylo A, Nowicka P, Carbonell-Barrachina AA, Hernandez F. Phenolic compounds, antioxidant and antidiabetic activity of different cultivars of Ficus carica L. fruits. J Funct Foods. 2016 25:421-32. https://doi.org/10.1016/j.jff.2016.06.015

12. Liu Y, Cao Y, Fang S, Wang T, Yin Z, Shang X et al. Antidiabetic effect of Cyclocarya paliurus leaves depends on the contents of antihyperglycemic flavonoids and antihyperlipidemic triterpenoids. $\quad$ Molecules. 2018;23(5):1042-59. https://doi.org/10.3390/molecules23051042

13. Machry RV, Pedroso HU, Vasconcellos LS, Nunes RR, Evaldt CA, Yunes Filho EB, Rodrigues TDC. Multifactorial intervention for diabetes control among older users of insulin. Revista de Saude Publica. 2018;52-60. https://doi.org/10.11606/S15188787.2018052000144

14. Chiasson JL. Acarbose for the prevention of diabetes, hypertension, and cardiovascular disease in subjects with impaired glucose tolerance: the Study to Prevent Non-InsulinDependent Diabetes Mellitus (STOP-NIDDM) Trial Endocr Pract. 2006;12(1):25-30. https://doi.org/10.4158/EP.12.S1.25

15. Paneni F, Luscher TF. Cardiovascular protection in the treatment of Type 2 diabetes: A review of clinical trial results across drug classes. Am J Med. 2017;120(1S):S17-S27. https://doi.org/10.1016/j.amjcard.2017.05.015.

16. Pantidos N, Boath A, Lund V, Conner S, McDougall GJ. Phenolic rich extracts from the edible seaweed, Ascophyllum nodosum, inhibit a-amylase and a-glucosidase: potential antihyperglycemic effects. J Funct Foods. 2014;10:201-09. https://doi.org/10.1016/j.jff.2014.06.018

17. Surendran S, Mookiah BE, Vijayakumar M, Rao CV. In-vitro and in-vivo hepatoprotective activity of Cissampelos pareira against carbon tetrachloride induced hepatic damage. Indian J Exp Biol. 2011;49(12):939-45.

18. Patel P, Harde P, Pillai J, Darji N, Patel B. Antidiabetic herbal drugs a review. Pharmacophore. 2012;3(1):18-29.

19. Prabhakar VK, Jaidka A, Singh R. In-vitro study on a- amylase inhibitory activity and phytochemical screening of few Indian medicinal plant having antidiabetic properties. Int J Sci Res Pub. 2013;3(8):1-6.

20. Jayaprasad B, Thamayandhi D, Sharavanan PS. Traditionally using antidiabetic medicinal plants in Tamil Nadu. Int J Res Pharm Biosci. 2012;2(1):1-8.

21. Middha SK, Usha T, Pande V. Insights into the causes and antihyperglycemic effects of Punica granatum rind in alloxan induced diabetic rats. Chiang Mai J Sci. 2016;43(1):112-22.

22. Kiran B, Lalitha V, Raveesha KA. Psoralea corylifolia L. A potent medicinal plant with broad spectrum of medicinal properties. Int J Fund Appl Sci. 2013;2(1):20-22.

23. Thomas VP, Sabu M, Prabhu Kumar KM. Amomum nilgiricum (Zingiberaceae), a new species from Western Ghats, India. PhytoKeys.

http://dx.doi.org/10.3897/phytokeys.8.2152

2012;8:99-104.

24. Kress WJ, Prince LM, Williams KJ. The phylogeny and new classification of the gingers (Zingiberaceae): Evidence from molecular data. Am J Bot. 2002;89(11):1682-96

25. Chen HY, Lin YC, Hsieh CL. Evaluation of antioxidant activity of aqueous extract of some selected nutraceutical herbs. Food Chem. 2007;104(4):1418-24.

https://doi.org/10.1016/j.foodchem.2007.02.004

26. Djeridane A, Yousfi M, Nadjemi B, Boutassouna D, Stocker P, Vidal N. Antioxidant activity of some Algerian medicinal plants extracts containing phenolic compounds. Food Chem. 2006; 97(4):654-60. https://doi.org/10.1016/j.foodchem.2005.04.028

27. Ruch RJ, Cheng SJ, Kalunig JE. Prevention of cytotoxicity and inhibition of intercellular communication by antioxidant catechins isolated from Chinese green tea. Carcinogen. 1989; 10(6):1003-08. https://doi.org/10.1093/carcin/10.6.1003

28. Ahmed F, Siddaraju NS, Urooj A. In-vitro hypoglycemic effects of Gymnema sylvestre, Tinospora cordifolia, Eugenia jambolana and Aegle marmelos. J Nat Pharm. 2011b;2(2):52-55. https://doi.org/10.4103/2229-5119.83950

29. Harish M, Ahmed F, Urooj A. In-vitro hypoglycaemic effects of Butea mospora Lam. leaves and bark. J Food Sci Food Technol. 2011; 51(2):308-14. https://doi.org/10.1007/s13197-011-0496-8

30. Persaud SJ, Al-Majed H, Raman A, Jones PM. Gymnema sylvestre stimulates insulin release in-vitro by increased membrane permeability. J Endocrinol. 1999;163(2):207-12. https://doi.org/10.1677/joe.0.1630207

31. Miguel GA, Fernandez EG, Bracamonte MS, Diaz-Guerra GM, Carranza FH. Association between peripheral vascular disease and other macrovascular and microvascular complications in diabetic patients. Endocrine Abstracts. 2015;37:EP484. https://doi.org/10.1530/endoabs.37.EP484

32. Nain P, Saini V, Sharma S, Nain J. Antidiabetic and antioxidant potential of Emblica officinalis Gaertn. leaves extract in streptozotocin-inducedtype-2 diabetes mellitus (T2DM) rats, J Ethnopharmacol. https://doi.org/10.1016/j.jep.2012.04.014

2012;142(1):65-71

33. Zlotek U, Mikulska S, Nagajek M, Swieca M. The effect of different solvents and number of extraction steps on the polyphenol content and antioxidant capacity of basil leaves (Ocimum basilicum L.) extracts. Saudi J Biological Sciences. 2016;23(5):628-33. https://doi.org/10.1016/j.sjbs.2015.08.002

34. Gubbiveeranna V, Nagaraju S. Ethnomedicinal, phytochemical constituents and pharmacological activities of Tridax procumbens: a review. Int J Pharm Pharm Sci. 2016;8(2):1-7. 
35. Apostolidis E, Kwon Y-I, Shetty K. Potential of cranberry-based herbal synergies for diabetes and hypertension management. Asia Pac J Clin Nutr. 2006;15(3):433-41.

36. Kwon Y, Vattem DA, Shetty K. Clonal herbs of Lamiaceae species against diabetes and hypertension. Asia Pac J Clin Nutr. 2006;15(1):107-18.

37. Kunyanga CN, Imungi JK, Okoth MW, Biesalski HK, Vadivel V. Total phenolic content, antioxidant and antidiabetic properties of methanolic extract of raw and traditionally processed Kenyan indigenous food ingredients. LWT - Food Sci Technol. 2012;45(2):269-76. https://doi.org/10.1016/j.lwt.2011.08.006

38. Bischoff H, Puls W, Krause HP, Schutt H, Thomas G Pharmacological properties of the novel glucosidase inhibitors BAYm1099 (miglitol) and BAY o 1248. Diabetes Res Clin Pract. 1985;1:53-62.

39. Ahmed F, Sairam S, Urooj A. Effect of various Ayurvedic formulations and medicinal plants on carbohydrate hydrolyzing enzymes and glucose uptake by yeast cells-an invitro study. J Pharm Res. 2009;2(3):563-68.

40. Ogundele AV, Otun KO, Ajiboye A, Olanipekun BE, Ibrahim RB. Antidiabetic efficacy and phytochemical screening of methanolic leaf extract of Pawpaw (Carica papaya) grown in north central Nigeria. JOTCSA. 2017;4(1):99-114. https://doi.org/10.18596/jotcsa.52813
41. Archit R, Gayathri M, Punnagai M. An in-vitro investigation into the mechanism of antidiabetic activity of selected medicinal plants. Int J Drug Dev Res. 2013;5(3):221-26.

42. McEwan R, Madivha RP, Djarova T, Oyedeji OA, Opoku AR. Alpha-amylase inhibitor of amadumbe (Colocasia esculenta) isolation, purification and selectivity toward $\alpha$ - amylases from various sources Afr J Biochem Res. 2010; 4(9):220-224

43. Wood PJ, Beer MU, Butler G. Evaluation of role of concentration and molecular weight of oat $\beta$-glucan in determining effect of viscosity on plasma glucose and insulin following an oral glucose load. Br J Nutr. 2000;84(1):19-23. https://doi.org/10.1017/S0007114500001185

44. Ahmed F, Sairam S, Urooj A. In-vitro hypoglycemic effects of selected dietary fibre sources. J Food Sci Technol. 2011; 48(3):285-89. https://doi.org/10.1007/s13197-010-0153-7

45. Goto T, Takahashi N, Hirai S, Kawada T. Various terpenoids derived from herbal and dietary plants function as PPAR modulators and regulate carbohydrate and lipid metabolism. PPAR. 2010;9:483958. https://doi.org/10.1155/2010/483958

46. Olaokun OO, McGaw LJ, Awouafack MD, Eloff JN, Naidoo V. The potential role of GLUT4 transporters and insulin receptors in the hypoglycaemic activity of Ficus lutea acetone leaf extract. BMC Complement Altern Med. 2014;14:269. https://doi.org/10.1186/1472-6882-14-269. 